\title{
Representations of Christmastide in Latin American Christmas Folk Songs: A Transitivity Analysis
}

\author{
Sthephanny Moncada Linares*, Xin Zhi-Ying \\ Xiamen University, China \\ *Email: sthephannyml@outlook.com
}

DOI https://doi.org/10.15294/lc.v15i1.25903

Submitted 27 August 2020. Revised 19 September 2020. Accepted 18 October 2020

\begin{abstract}
Considered as the universal language, music has been historically a means of communication and personal expression about the inner and outer world of its creator, it is present in almost every social activity of human beings as in the habitual religious celebration of Christmas across the largely Catholic countries. Therefore, the present paper will provide a descriptive text analysis of ten traditional Latin American Christmas folk songs on the base of the transitivity system informed by the Hallidayan Systemic Functional Linguistics theory. To reach this goal, both a quantitative and qualitative research method approach was applied. Findings indicated that among the six analyzed transitivity process types, the material processes $(32 \%)$ dominate the construal of the musical pieces, followed by the mental (23\%), behavioral (18\%), and relational realizations $(13 \%)$ whereas the verbal and existential processes are relatively low all together representing an overall frequency of $14 \%$. This reveals the singers' attempt to represent the Christmas season as a nostalgic time leap, an immediate enjoyment, and a rewarding exchange.
\end{abstract}

Keywords: christmas; folk music; Latin America; representation; transitivity system

\section{INTRODUCTION}

Every year in every corner of the world where Christmastime is celebrated, radio local stations start playing holiday music $24 / 7$, announcing the beginning of this season and setting a celebratory mood. As a pivotal element of the cultural phenomenon of Christmas, music has become one of the preferred vehicles to impinge directly on sentiments and thus, call for a collective experience of reconnection with home and close social circles, re-evaluation of the past, and projection towards the future.

Unlike the traditional festive religious songs widely popular in North America and Europe that illustrate ancient pastoral traditions with choirs and lyrics referring the coming of Jesus Christ and the rejoice for his birthday, in Latin America, Christmas music has been mainly composed for dancing purposes under the label of tropical music, that is, a category employed in the music industry to designate Latin rhythms originated in the Hispanophone Caribbean such as salsa, guaracha, cumbia, vallenato, etc. Classical carols derived from old British winter themes such as 'Let it snow,' 'Silver Bells,' 'God rest ye merry, gentlemen,' 'O holy night,' and some others, are replaced in Latin America by more ce- lebratory and danceable songs like Faltan cinco pa' las doce (Five minutes to Midnight); Año Nuevo (New Year); Año Nuevo, vida nueva (New Year, new life); El Año Viejo (Old Year); Árbolito de Navidad (Christmas tree); La víspera de Año Nuevo (New Year's Eve); El mensaje de Navidad (The Christmas message); Son para gozarlas (They are to enjoy); Feliz Nochebuena (Merry Christmas Eve); and Mamá, ¿dónde están los juguetes? (Mom, where are they toys?), all interpreted by artists from Venezuela, Mexico, Cuba, and Colombia. These latter were the ones considered as a corpus to conduct this analysis and imply a more secular representation of Christmas.

Music is undeniably one of the major influences on Latin American people, it features lyrics that address daily life practices and personal experiences. For example, during Christmastide, most of the songs describe the typical celebratory rituals involving Christmas and New Year's Eve that mainly include cooking and enjoying food, gift-giving, well-wishing, as well as drinking, singing, and dancing. Within this context, a theory of grammar like the one postulated by the Systemic Functional Linguistics (Halliday, 1978, 1985, 1994, 2003; Halliday \& Hasan, 1985; Halliday \& Matthiessen, 2004, etc.), from its Transitivity system, allows broadening the comprehension of 
musical compositions (one of the most common text types) to elucidate how individuals portray meaning and represent it as a reflection of their own experiences with the physical, mental, and social world (Fairclough, 2003; Halliday, 1994; Halliday \& Matthiessen, 2004). Hence, the present paper seeks to analyze the lexicogrammar choices in ten Latin American Christmas folk songs to unveil the discursive representations arising from this festive season.

Language is known to be meta-functionally arranged in the sense that it construes and portrays the world of experiences by offering people choices to enact social roles and relations between the producer of a sign, the receptor, and the object through the interpersonal metafunction and its systems of mood (i.e., declarative, imperative, and interrogative), polarity (i.e., positive and negative), and modality (i.e., modal verbs); to transform meaning into texts using the textual metafunction and its theme-rheme structure, and finally, to represent several objects, their relations, and processes through the ideational metafunction and its transitivity system (i.e., process types, participant roles, and circumstances), being this latter the basis of the present analysis.

Under the theoretical principles of the ideational metafunction of language, there is the transitivity system by which people construe their inner and outer world experience of change with regards to the configuration of a process indicated by a verb phrase, participants in charge of the enactment of the process or impacted by it, and optional accompanying circumstances realized by adverbial or prepositional groups (Halliday, 1994, 2003; Halliday \& Matthiessen, 2004; Matthiessen, Martin, \& Painter, 1997). This system has been long used to conduct systematic text analysis as it makes possible to explore and unveil the speaker's cosmovision through the choices of content in a created text that will ultimately allow "to say sensible and useful things about [it]" (Halliday, 1994, p.36).

The major and most recurrent processes in any text type have been documented to be the material, mental, and relational with their subtype, followed by the verbal, behavioral, and existential, all attended by the corresponding participant roles as briefly explained below.

Material. It construes doings and happening of concrete and abstract phenomena in which two participants are directly involved. One is the 'actor,' who performs the material deed, and the other one is the optional 'goal,' who is either impacted by the doing or benefited from it.

Mental. It depicts the perceptive, cognitive, desiderative, and emotive sensing experience over a phenomenon. The 'senser,' an animate or inanimate participant, is the primary subject engaged in the conscious process, while the 'phenomenon' constitutes what is sensed including an object, an abstraction, a conscious being, and an action. Relational. It construes the states of being and having of a subject, and comprises mainly two modes of operation, an attributive and an identifying. A commonly attributive clause characterizes the class membership or 'attribute' of a 'carrier,' and an identification clause implies that " $x$, the value, identifies the identity or label of $y$, the token." Verbal. It construes the interchange of symbolic meaning by a 'sayer,' a human or human-like speaker who tells, announces, claims, reports, etc. a 'verbiage,' that is, the content of what is said to a 'receiver', who is usually marked by the addition of to. Behavioral. It construes, as an activity, the physiological and psychological behaviors of subjects. Behavioral processes are partly mental and partly material in the sense that they involve a conscious process identified as a behavior and corporal postures and hobbies, all performed by a 'behaver.' Existential. It construes the existence of an entity or event, the 'existent,' and is frequently signaled by the existential there. A summary of the above information is illustrated in Table 1 and Table 2.

Research on the field of linguistic and discourse analysis has tried to reveal the hidden messages encoded within diverse songs genres and styles of music. It is the case of Fonseca (2015), who found that accordion music reproduces gender stereotypes by building specific versions of men and women from the base of certain societal power structures, similarly, Nieto (2018) indicated that there has been an evolution and reversal of gender roles concerning loving relationships that have been reflected in the content of love songs. Through a comparative investigation, Hằng (2016) discovered that the image of mother depicted in English and Vietnamese songs have more commonalities than differences in the sense that in both populations, and despite the historical and cultural factors, most mothers during wartime worry about their children's safety and wellbeing, and during peacetime, they play the role of caretakers, teachers, and loyal friends. Friday (2018), Gusrayani, (2008), Harbi, et al. (2019), Kipsang (2016), Paro (2013), among others, have conducted related studies.

Notwithstanding the existing research, through a literature review process, it became evident the lack of study to those compositions regarding one of the most important and me- 
morable seasons of the year, that is, Christmastide, and more importantly, its representations emerging from the view of the Latin American society. Therefore, to contribute to the theoretical-practical study of Latin American Christmas folk songs, the analysis of ten musical pieces is presented below. This paper first introduces the applied theory, it then outlines the followed methodology, and finally, offers, in detail, the corresponding outcomes together with a concluding remark.

\section{METHODS}

The corpus selected for the present analysis comprises ten Latin American Christmas folk songs selected from repeating patterns of cooccurring terms regarding the practice of Christmastide.

It was applied a combination of a quantitative and qualitative methodical approach, which sought to provide a descriptive and thorough understanding of the corpus guided by the theoretical fundaments of the Transitivity system under the Systemic Functional Linguistics. The methodological steps undertaken comprised (a) an identification phase of the ranking clauses as the basic unit of analysis; (b) a categorization phase of the constitutive elements of the transitivity system, that is, the processes, the participants, and the circumstances types; and lastly, (c) an interpretation phase on the findings.

\section{RESULT AND DISCUSSION}

Based on the transitivity analysis conducted to the ten selected Christmas folk songs from Latin America, a total of 167 process types were identified together with their participants and circumstantial elements (see Table 3).

The material processes present a higher level of occurrence accounting for 32\% (53 realizations) of the corpus. Mental processes are placed second with 23\% (38 realizations) of frequency. Meanwhile, behavioral, relational, verbal, and existential processes have an overall occurrence of $18 \%$ (30 realizations), $13 \%$ (22 realizations), $8 \%$ (14 realizations), and 6\% (10 realizations) correspondingly.

The extracted semantic macrostructures (i.e., topics) of the studied songs and the exploration of their microstructures via the transitivity system resulted in the depiction of the following three representations employed by Latin American singers to construe the overall notion of Christmas:

\section{A Nostalgic Time Leap}

From 53 material realizations, 32\% correspond to motion verbs in Spanish (e.g., is leaving, is gone, comes, etc.) that imply the abstract process of approaching and passing of time during the

Table 1. Process and participant types adapted from Matthiessen, Martin, \& Painter (1997)

\begin{tabular}{|c|c|c|}
\hline Process Types & Participant & $\begin{array}{l}\text { Examples } \\
\text { (Participant in italics, Process in bold) }\end{array}$ \\
\hline $\begin{array}{l}\text { Material } \\
\text { Happening } \\
\text { Doing }\end{array}$ & Actor, Goal & $\begin{array}{l}\text { Malcolm (actor) learns about quantum physics (goal). } \\
\text { Quantum physics (actor) is learned by Marcom (goal). }\end{array}$ \\
\hline $\begin{array}{l}\text { Mental } \\
\text { Perception } \\
\text { Cognition } \\
\text { Affection } \\
\text { Desideration }\end{array}$ & $\begin{array}{l}\text { Senser, } \\
\text { Phenomenon }\end{array}$ & $\begin{array}{l}\text { He (senser) smelled the danger (phenomenon). } \\
\text { I (senser) understand you (phenomenon). } \\
\text { It (senser) hurt her feelings (phenomenon). } \\
\text { Heidy (senser) wants to have more money (phenomenon). }\end{array}$ \\
\hline $\begin{array}{l}\text { Relational } \\
\text { Attributive } \\
\text { Possessive } \\
\text { Intensive-identifying }\end{array}$ & $\begin{array}{l}\text { Carrier-Attri- } \\
\text { bute } \\
\text { Possessor- } \\
\text { Possessed } \\
\text { Token-Value }\end{array}$ & $\begin{array}{l}\text { John (carrier) is a wonderful man (attribute). } \\
\text { She (possessor) had a fortune (possessed). } \\
\text { Philip (token) is the smartest student here (value). }\end{array}$ \\
\hline Verbal & $\begin{array}{l}\text { Sayer, Re- } \\
\text { ceiver, Target, } \\
\text { Verbiage }\end{array}$ & $\begin{array}{l}\text { The news (sayer) says that the war is coming to an end. } \\
\text { I told him (receiver) to stay away from my family. } \\
\text { People criticized the deputy (target) for his dishonesty. } \\
\text { I'm grateful for your help (verbiage), she said. }\end{array}$ \\
\hline Behavioral & Behaver & He (behaver) smiled at me cheerfully. \\
\hline Existential & Existent & There is a newly discovered tribe (existent) in Africa. \\
\hline
\end{tabular}


Table 2. Circumstance types adapted from Matthiessen, Martin, \& Painter (1997)

\begin{tabular}{|c|c|c|}
\hline $\begin{array}{c}\text { Circumstance } \\
\text { Types }\end{array}$ & Probe & Examples \\
\hline \multicolumn{3}{|l|}{ Extent } \\
\hline Spatial & How far? & Mary has been elected as president two times. \\
\hline Temporal & How long? & It lasted all day. \\
\hline \multicolumn{3}{|l|}{ Location } \\
\hline Spatial & Where? & The match took place in Madrid. \\
\hline Temporal & When? & They'll play next week. \\
\hline \multicolumn{3}{|l|}{ Manner } \\
\hline Means & With what? & Robert killed her with a shotgun. \\
\hline Quality & How? & She runs slowly. \\
\hline Comparison & What like? & We finished it as fast as we could. \\
\hline \multicolumn{3}{|l|}{ Cause } \\
\hline Reason & Why? & I passed the exam thanks to my classmate. \\
\hline Purpose & What is it for? & Anne bet hoping to win. \\
\hline Behalf & For whom? & She did it for me. \\
\hline Contingency & On what condi- & \\
\hline Condition & tions? & We'll have to stop the game in the event of a storm. \\
\hline Concession & Despite what? & Beth won the lottery despite her bad luck. \\
\hline Default & $\begin{array}{c}\text { In the lack of } \\
\text { what? }\end{array}$ & He was freed in the absence of evidence. \\
\hline Accompaniment & With whom? & Amy came with me. \\
\hline Role & What as? & As the manager, she fired everyone. \\
\hline Matter & About what? & As for me, I won't press charges. \\
\hline Angle & Says who? & $\begin{array}{l}\text { According to the WHO organization, the pandemic is } \\
\text { growing fast. }\end{array}$ \\
\hline
\end{tabular}

Christmas season. The main actors are portrayed by the inclusion of a lexicon that evokes New Year's Eve (e.g., the old year; the year; the bearded year; another year; etc.), referring time and its measurement (e.g., the time; the dawn; the midnight), and indicates the conventional seasonal symbols (e.g., the Christmas bells; the joy; the Christmas tree). To a lesser extent, two instances of relational processes including its participants and circumstances (e.g., it's five to twelve; the night being serene), plus three addition of three verbal processes (e.g., announcing; the clock warns us; I already say goodbye, Compay, to this Christmas) encode this sense of temporal transition.

Being Christmas a celebration that commonly lasts 12 days, starting from December 25 with the Christmas Day to January 5 with the Epiphany Eve (in some Latin American communities like the Colombian, it traditionally begins on December 24 and stretches until January 6), this Western holiday marks the end and arrival of a new year and is psychologically accompanied with a transient mood state. The reawakening of memories and the opportunity of renewing or strengthening social relationships during this fleeting period of the year triggers in people the powerful emotional experience of 'nostalgia' as noted by Batcho (cited by American Psychological Association, 2011) and Rosewarne (2018).

Through the analysis of the corpus, this sentimental yearning is particularly evident in the chosen mental processes of affection (e.g., it makes the sad when December arrives; suffers the sorrows), cognition (e.g., they don't want to remember the New Year's party and Aguinaldo), and perception (e.g., the memories that hurt us), which seem to emphasize the negative affects felt by the personae of the songs (e.g., some hearts; the one who; there are others; etc.) as a result of their reminiscence exercise that brings to the fore their unpleasant past experiences in the form of a yearly parallel between what has changed and what remains.

Christmastide, however, not only entails recognizing and voicing the 'darkness' of the last year (e.g., last year she said [verbal process] she would marry me this year and everything has been a lie, that's why my life cries) but also serves as a catharsis mechanism that, driven by the bittersweet nostalgia sentiment, allows individuals to commit themselves into forgetting the sorry past and 
Table 3. Frequency of Process Types

\begin{tabular}{lccccc}
\hline Process Types/Songs & $\# 1$ & $\# 2$ & $\# 3$ & $\# 4$ & $\# 5$ \\
\hline Material 53(32\%) & $750 \%$ & $950 \%$ & $225 \%$ & $572 \%$ & $556 \%$ \\
Mental 38(23\%) & & & & & \\
Affective & 2 & 1 & 0 & 0 & 0 \\
Cognitive & 0 & 1 & 0 & 0 & 0 \\
Perceptual & 1 & 2 & 0 & 0 & 0 \\
Desiderative & $0322 \%$ & $1528 \%$ & 0 & 0 & 0 \\
Behavioral 30(18\%) & $17 \%$ & 0 & $225 \%$ & 0 & $111 \%$ \\
Relational 22(13\%) & & & & & \\
Intensive-Attributive & 0 & 0 & 2 & 0 & 2 \\
Intensive-Identifying & 0 & 0 & 1 & 0 & 0 \\
Possessive-Attributive & 0 & 0 & 0 & 0 & 0 \\
Circumstantial & $117 \%$ & 0 & $0337 \%$ & 0 & $0222 \%$ \\
Verbal 14(8\%) & $17 \%$ & $211 \%$ & $113 \%$ & 0 & $111 \%$ \\
Existential 10(6\%) & $17 \%$ & $211 \%$ & 0 & 0 & 0 \\
$\mathrm{~N}=167$ & $\mathrm{~N}=14$ & $\mathrm{~N}=18$ & $\mathrm{~N}=8$ & $\mathrm{~N}=7$ & $\mathrm{~N}=9$ \\
\hline
\end{tabular}

make way for achieving a brighter future.

The aforementioned is represented in the lyrics of the song El mensaje de Navidad (The Christmas message), which, through the mental process of cognition 'to forget' (e.g., let them forget the old year; let them forget the memories) and one instance of the behavioral process 'let die' (e.g., let memories die) encourages the audience to stop thinking about the memories and conversely, embrace a new starting as it is indicated by the relational: intensive-identifying (e.g., more cheerful the days will be) and behavioral (e.g., the coming year, caramba, I will sing and enjoy again) linguistic realizations present in some of the other musical compositions. In this sense, the suffering of the 'temporal or seasonal nostalgia' "becomes a practice of forgetting" (Santesso cited by Rosewarne, 2018, p.94) after having purged the internal pain by the power of the forthcoming goals and the filial reencounters as explained below.

Thus, the traditional New Year's resolutions constitute a fresh start to move on to a more optimistic future and leave the nostalgia behind. This is perfectly encapsulated within the lines of the studied songs, thus, $12 \%$ (five realizations) of the mental processes depict the singer's resolutions addressed to third parties and which, for this particular corpus, are embodied in the ethos of well-wishing intentions concerning the prospective attainment of immaterial goods such as prosperity, good luck, and a long-lasting life (e.g., let them be filled with good; I wish them a prosperous New Year and adventure for those coming; we're going to wish him/her good luck and may God keep him/ her from the dead). These expressions of goodwill are emphatically stressed by the singers' verbal processes in the song El mensaje de Navidad (The Christmas message) interpreted by Diomedes Díaz (e.g., for those people goes the message of affection; preaching this message I have come, to tell you with soul and greatness).

A last collateral effect of the Christmas nostalgia found in the corpus reveals the intrinsic need of individuals to reconnect with the family bonds that, according to Miller (2017), could represent one of the most significant contributions of Christianity to the development of this celebration as it is the central image of the family. This relationship of parents to a child is explicitly portrayed in the analyzed songs by highlighting Christmastide as a time of homecoming in which a maternal figure (e.g., the pretty old lady; mother; mom) awaits the arrival of the beloved one and this latter appears at her encounter. Material processes accounting for motion in space (e.g., to leave the party; I'm running home) and three behavioral constructions implying the action of hugging (e.g., to hug mom) and waiting (e.g., who is waiting for me; we will wait together) denote the great importance of the domestic sphere in the temporal transition from the old to the new year. It is not surprising then to find that in some Latin American societies "many people interrupt festivities before midnight on New Year's Eve to go home" (Mullins, 1997, p.64), however, not everything is enjoyment and there are some others who deeply 
long for this reunion as they are far away. This devotional yearning is illustrated in existential (e.g., I am so far; for the one who spends New Year away; as the one who stayed in the hills) and material processes (e.g., another Christmas without seeing my people) together with the stress on their sense of emptiness transmitted via relational: possessive realizations (e.g., they have no happiness) and their plea not to be forgotten conveyed by verbal and mental instances (e.g., mother, I humbly ask you to remember me on New Year's Eve).

Ultimately and as perfectly indicated by Rosewarne (2018), nostalgia is a sentiment especially fixated on time and is pivotal in the depiction of Christmas as it revives the past but also sentimentalizes it, it elevates its meaningfulness. In this sense, the interpreted corpus represents this celebratory season as a bittersweet nostalgic time leap that places at its locus reminiscence, projection, and filial connectedness.

\section{An Immediate Enjoyment}

"Christmas is coming: Be merry for Christmas only comes once a year" highlights Ownby (1999) in his book, this seasonal sentiment could be one of the most anticipated and cherished by people. It is within this context of collective effervescence that Latin Americans hold celebrations with friends, family, and neighbors as an opportunity to gather and share lavish dinners, drink, dance to the rhythms of festive music, exchange commodities, among some others. Altogether, these rites are a reflection of the well-known 'festive indulgence' resulting from giving way to one's desires during Christmastide, a season in which most individuals momentarily allow themselves to have a time of enjoyment without the restraints of the old year (Evans, 2000).

This "festival for the feelings (...) the seasonal cycle of plenitude" (Nissenbaum, 1996, p.208), or simply the "parade of excess" (Ace, 2003, p.10) is well illustrated through the analyzed songs through the recurrent use of the material and behavioral processes. Thus, verbs of the kind 'to drink, to toast, to eat, to party, to sing, etc.' are employed to signal the different actions performed by people when participating in these gaieties, together with the circumstance of manner 'with happiness' used, in some cases, to emphasize that these activities happen pleasingly (e.g., I go out to party; drinking and drinking, with happiness; let's toast; I'm going to eat cakes; I'm going to have fun; etc.). Regarding this last point, it is noteworthy that the song Feliz Nochebuena (Merry Christmas Eve) includes a large number of mental realizations employing the verb 'I like' to express which Christmas rituals the singer enjoys the most (e.g., I like dancing, I like drinking, I like laughing; I like singing).

Moreover, relational processes both attributive and possessive indicate the positive loaded connotations singers assign to the instances of celebrations happening during the Christmas and New Year's Eve, and which are complemented with attributives such as 'happy, good, pretty, bright' to describe how these specific dates trigger in people cheerful emotions (e.g., they get cheerful; Oh how good is Christmas Eve; it's the most beautiful time of the year; etc.), even to the point of becoming an event for couples (e.g., it's already a milestone for lovers).

Additionally, it is noteworthy to mention that among the referred participants there is not an explicit reference to the domestic focus, that is, the traditional family model as depicted by the Christianity, instead the songs seem to portray it from a wider social sphere that mostly includes friends, lovers, and acquaintances who get together to party and follow their fleeting sense of selfindulgence (e.g., I want to spend it with you; spend it with friends; spend it with siblings; etc.). This idea is also supported by the need of individuals to interrupt the celebration and before midnight to reaffirm the filial bonds with the family, particularly with the mother (e.g., I'm running home to hug mom) as already explained in the former point.

In broad terms, it can be observed that the corpus seems to accentuate the delightful emotional sense of immediate rejoice that people experience during these two holidays, a temporary moment's respite from the past hardships, and the uncertainty of the future.

\section{A Rewarding Exchange}

The analysis of the corpus unveiled that singers resorted to a higher degree to the employment of material processes to draw attention to people's social behavior in terms of rewards. Being Christmas, a celebratory season happening annually throughout the life course, it arises in individuals the expectations to be rewarded after a year's worth of ups and downs, a goal traditionally achieved through the exchange of goods among friends, family members, and neighbors, that is, the main recipients.

During Christmastide, especially at the time of Christmas Eve, people get together to perform the ritual of gift-giving and receiving, a symbolic exchange (Miller, 1993) by which they demonstrate the value they assign to their dearests inasmuch they mutually satisfy their immediate needs and exhibit their good faith. According to 
Haas and Deseran (1981), the core of this type of transaction lies in its potentiality to portray the nature of the relationship between the receiver and the giver in the establishment of affective social bonds. This is explicitly encoded in verbs of the type 'give (me), send (me), and bring (me),' which imply a request from the speaker to be compensated either through intangible commodities like good health and love or tangible ones as money, hugs, and toys (e.g., what are you going to gift me; send me a big hug; mom, where are my toys?; etc.). It should be noted that the lyrics of the selected songs make a particular accent on those immaterial goods.

Likewise, this festivity season also allows participants to voice accomplishment in the form of gratitude for the virtuous fortune brought by the outgoing year and as a direct exchange for their good deeds. This is demonstrated in the data, although in a lesser extent, through the material processes realized by the verb 'to leave (me)', which denotes to give away something (e.g., it left me a goat, a goat, a black donkey, a white mare, and a good mother-in-law; it has left me very good, very beautiful things). From a more secular viewpoint, it bears resemblance to the classical nature of the Thanksgiving holiday celebrated majority in the United States; despite in Latin America this grateful acknowledgment commonly takes places on the same day of New Year's Eve and not on a separate date as it is the case of North America.

This sense of reciprocity that implies receiving something in reply for something given previously, enhances individuals' desideration for maximizing rewards and minimizing possible punishments or losses. Thus, on the one hand, the studied songs stress on the misbehaving acts performed by people throughout the year by signaling them via two mental processes of affection (e.g., forgetting heavenly money; Christ child knew it), together with two material (e.g., if people use gold and nothing else; would it be that you did something $b a d)$, and one behavioral realization (e.g., they care about luxury and appearance), instances that highlight their overconcern for the possession of material goods and which, in turn, distort the symbolic exchange of a deserved reward (e.g., if they have a sincere heart, they will see the stars in the $s k y$ ). On the other hand, the corpus unveils the side effects of this negative attitude through the inclusion of mental processes of affection of the type 'feel bad and do not love me,' which reflect the unfavorable feelings perceived by those who supposedly showed a socially undesirable behavior (e.g., today I feel very sad; Christ child does not love me; do not feel sad anymore).
This interplay between the awareness of the good and bad actions might serve as a mechanism of generosity to discipline people since as stated by Belk and Coon (1993), subjects mutually control their necessities and therefore, decide whether it is worthy to reward or penalize. Suffice to evoke the explicit mentions presented in the lyrics Mamá, ¿dónde están los juguetes? (Mom, where are they toys?) with the mental and material allusions (e.g., I want to please you; Christ child didn't bring them). At last, this need for compensation and the avoidance of sanctions depicts Christmas as a suitable time to stimulate the practice of rewarding exchange.

\section{CONCLUSION}

From the analysis conducted on the selected corpus, it can be concluded that material processes $(32 \%)$ are the ones dominating the construction of the musical pieces; these allow singers to show the concrete and physical actions either performed by themselves and the individuals mentioned in their compositions or indicate how their behavior is affected by these actions. Alongside, participants are presented as well in terms of what they do, what have they experienced, what they feel, and how they behave through the use of the mental (23\%), behavioral (18\%), and relational $(13 \%)$ transitivity processes.

In overall, it can be stated that the leading discourse regarding Christmastime in the Latin American context represents it as a transient nostalgic time, as a temporal landmark of enjoyment that leads to over self-indulgence, and as a season to receive and exchange gratifications. It should be highlighted that the present analysis provides an initial theoretical-practical contribution to the literature of Latin American folk songs as a portrayal of its social-cultural identity, this grounded in the field of discourse analysis and linguistics. Further research is recommended on the interpretation of the same topic but including a larger number of corpora to enhance the validity and reliability of the outcomes, or the comparison of the nativity themes arising from Christmas songs originated in diverse cultures across the world.

\section{REFERENCES}

Ace, C. (2003). Before you wish for an "old-fashioned" Christmas. In C. Ace (Ed.), Stories behind the Great Traditions of Christmas (pp. 9-20). Zondervan.

American Psychological Association. (2011, December). 'Tis the Season for Nostalgia: Holiday Remi- 
niscing Can Have Psychological Benefits.

Belk, R., \& Coon, G. (1993). Gift Giving as Agapic Love: An Alternative to the Exchange Paradigm Based on Dating Experiences. Journal of Consumer Research, 20(3), 393-417.

Evans, P. (2000). Satirizing the Spanish Christmas: Plácido (Luis García Berlang, 1961). In M. Connelly (Ed.), Christmas at the movies: Images of Christmas in America, British and European cinema (pp. 211-221). I.B. Tauris Publishers.

Fairclough, N. (2003). Analyzing Discourse: Textual Analysis for Social Research. Routledge.

Fonseca, C. (2015). Discursivas de representación de género en la música de acordeón. Revista Palobra, "Palabra Que Obra,"11(11), 162-181.

Friday, F. (2018). A critical stylistic analysis of Cobhams Asuquo's rap song "Boosit." International Journal of Innovative Research and Advanced Studies, 5(8), 231-239.

Gusrayani, D. (2008). Thematic and transitivity analysis of children's songs and stories. Jurnal Sastra Inggris, 8(1), 61-75.

Haas, D., \& Deseran, F. (1981). Trust and Symbolic Exchange. Social Psychology Quarterly, 44(1), 13.

Halliday, M. (1978). Language as social semiotic: The social interpretation of language and meaning. Edward Arnold.

Halliday, M. (1985). An introduction to functional grammar. Edward Arnold.

Halliday, M. (1994). An introduction to functional grammar. Edward Arnold.

Halliday, M. (2003). On language and linguistics. Continuum.

Halliday, M., \& Matthiessen, C. (2004). An Introduction to Functional Grammar. Hodder Arnold.

Hằng, T. T. T. (2016). Mother image in English and Vietnamese songs - A literary analysis using transitivity system in systemic functional linguistics perspective (Master's dissertation, Vietnam National University, Vietnam).
Harbi, S., Abdul Jabar, M., Md Nor, A., \& Muhammad Isa, N. (2019). 'Hey, Jude! I wanna hold your hand': Transitivity process analysis on popular songs by the Beatles. International Journal of Language Education and Applied Linguistics, $9(1), 45-54$.

Kipsang, S. (2016). The construction of gendered ideology in alcohol, bhang, and sex referenced Kenyan popular music (Master's dissertation, Egerton University, Kenya).

Matthiessen, C., Martin, J. \& Painter, C. (1997). Working with functional grammar. Arnold.

Miller, D. (1993). Unwrapping Christmas (D. Miller (Ed.)). Oxford University Press.

Miller, D. (2017). Christmas: An anthropological lens. HAU: Journal of Ethnographic Theory, 7(3), 409442.

Mullins, G. (1997). Culturegrams: The Americas and Europe. Ferguson.

Nieto, R. (2018). The social evolution of the expression of love through music: A contrastive analysis of transitivity in hit song in English and Spanish (1950-2009) (Doctoral dissertation, Universidad Complutense de Madrid, Spain). http:// eprints.ucm.es/46903/1/T39725.pdf

Nissenbaum, S. (1996). Under the Christmas tree: A battle of generations. In S. Nissenbaum (Ed.), The Battle for Christmas. Random House.

Ownby, T. (1999). American dreams in Mississippi: Consumers, poverty \& culture, 1830-1998. University of North Carolina Press.

Paro, D. (2013). Representations of women in American rap: A systemic-functional and critical discourse analysis (Universidade Federal de Santa Catarina, Brazil). http://www.lle.cce.ufsc.br/docs/ tccs/2e9b761d07c426f0b0e60ef0a7eea285.pdf

Rosewarne, L. (2018). "I feel, for some reason, that this is a good time of year for looking backwards." In L. Rosewarne (Ed.), Analyzing Christmas in Film (pp. 93-170). Lexington Books. 